\title{
ADSORPTION OF CR(VI) ION FROM AQUEOUS SOLUTIONS BY SOLID WASTE OF POTATO PEELS
}

\author{
Nidhal M. Sher Mohammed* and Haydar A. Mohammad Salim \\ Dept. of Chemistry, Faculty of Science, University of Zakho, Kurdistan Region - Iraq.
}

Received: Jun. 2017 / Accepted: Aug., 2017 / Published: Sept., 2017

https://doi.org/10.25271/2017.5.3.392

\begin{abstract}
:
Pollution of wastewater with heavy metal has always been a serious problem to the environment. Chromium is considered one of the most noxious heavy metals. Adsorption is now reorganized as an alternative technology of defence for chromium removal due to local availability, technical efficiency and cost effectiveness. Potato peel powder can be used as a low cost biosorbent to remove hexavalent chromium from aqueous solutions under various experimental conditions. Different parameters including equilibrium contact time, initial metal ion concentration, potato peel dose, $\mathrm{pH}$ and temperature were studied through a number of batch sorption experiments. Both the Langmuir and Freundlich were found to fit the adsorption isotherm of $\mathrm{Cr}$ (VI) ion onto potato peel. The Langmuir adsorption capacity was found to be $1.97 \mathrm{mg} / \mathrm{g}$ while Freundlich constants including Kf and $\mathrm{n}$ were 1.57 and 2.5 , respectively. The adsorption kinetic was found to be more fit with the pseudo-first order model. This study showed a high efficiency of potato peel for the biosorption of $\mathrm{Cr}$ (VI) ion from aqueous solutions.
\end{abstract}

KEYWORDS: Adsorption; Chromium (VI); Isotherm; Potato Peel; Wastewater.

\section{INTRODUCTION}

Pollution of wastewater with heavy metals is considered a serious environmental issue, because these metals are not biodegradable and can be accumulated in living tissues (Deng et al., 2006). These metals can be present with high concentrations in waste water that discharges from electroplating industries and most mining activities. Chromium $(\mathrm{Cr})$ is considered one of the most noxious heavy metals. Hexavalent chromium compounds have high toxicity and they can be carcinogenic, mutagenic and often reason for lung cancer (Sikaily et al., 2007; Li et al., 2008). The united states environmental protection agency limits for chromium in discharge into inland surface water to be $0.1 \mathrm{mg} / \mathrm{L}$ (EPA, 1990).

There are various methods have been employed in wastewater treatment technology to remove heavy metals from aqueous solutions including electrochemical treatment, membrane separation, precipitation, reverse osmosis, evaporative recovery, ionic exchange and adsorption (MonserandAdhoum, 2002; AnirudhanandRadhakrishnan, 2008). Most of these procedures are ineffective at low $\mathrm{Cr}(\mathrm{VI})$ concentrations and costly. However, adsorption is now reorganized as an alternative technology of defence for chromium removal due to local availability, technical efficiency and cost effectiveness (Li et al., 2008). Recently, considerable attention has been given to removal of $\mathrm{Cr}(\mathrm{VI})$ from aqueous solution using a number of materials such as activated carbons (Mohan andPittman, 2006), mineral oxides, biological materials (Bailey, et al., 1998; Sallau et al., 2012), agroindustry waste residues (Hasan et al., 2008), fruit peelings (Krishna andSwamy, 2012) and leaves (Prasad et al., 2012).

To the potato industry, management of potato peel as waste product causes a considerable problem. Therefore, it needs to find an integrated, environmentally-friendly solution. Potato peel (PP) can be used as a low-cost biosorbent and alternative for more costly wastewater treatment processes (GuechiandHamdaoui, 2011).
The present study investigated adsorption efficiency of chromium (VI) ions from aqueous solutions on potato peels as solid waste and low cost biosorbent. Different parameters including equilibrium contact time, initial metal ion concentration, potato peel dose, $\mathrm{pH}$ and temperature were studied through a number of batch sorption experiments to optimize the adsorption equilibrium, adsorption capacity, adsorption isotherms and adsorption kinetic.

\section{MATERIALS AND METHODS}

\subsection{Materials}

An analytical reagent grade of potassium dichromate (K2Cr2O7) was taken to prepare $(1000 \mathrm{mg} / \mathrm{L})$ stock solution of $\mathrm{Cr}$ (VI) in deionized water and stored in a dark place. This solution was used to prepare working solutions by appropriate dilutions. 1,5-Diphenylcarbazide solution was prepared by dissolving $250 \mathrm{mg}$ in $50 \mathrm{~mL}$ acetone and stored in a brown volumetric flask. Hydrochloric acid and sodium hydroxide (Fisher-Scientific, UK) were used for $\mathrm{pH}$ adjustment. $1 \mathrm{M} \mathrm{HCl}$ was used to clean all glassware followed by rinsing in deionised water.

\subsection{Biosorbent preparation}

Potato peels (PP) were brought from local restaurants (Duhok/Kurdistan Region-Iraq) and washed thoroughly and soaked for 2-3 hrs in deionized water. Then, PP were rinsed with $0.1 \mathrm{MHCl}$ to make the surface of PP more protonated and extent the strength of attraction of $\mathrm{Cr}$ (VI) ions in the solution (Mutongoet al., 2014). The biosorbent was dried in an oven at $100 \mathrm{oC}$ for $3 \mathrm{hrs}$ then burned for $2 \mathrm{hrs}$ at $750 \mathrm{oC}$ in the furnace. The burned potato peels were then ground to $100 \%$ and sieved passing $40 \mu \mathrm{m}$ and stored in desiccators for further use. Approximately $10 \mathrm{~kg}$ from fresh potato peel can give $100 \mathrm{~g}$ peel powder. Table 1 shows analysis of the charcoal of potato peels.

\footnotetext{
${ }^{*}$ Corresponding author

This is an open access under a CC BY-NC-SA 4.0 license (https://creativecommons.org/licenses/by-nc-sa/4.0/) 
Table 1. Characteristics of the adsorbent" (Amanet al., 2008)

\begin{tabular}{|c|c|}
\hline Characteristics & Values \\
\hline Ash (\%) & 6.96 \\
\hline Carbon (\%) & 27.85 \\
\hline Moisture (\%) & 1.6 \\
\hline Volatile Matter (\%) & 60.85 \\
\hline Bulk density (\%) & 0.37 \\
\hline Iodine number (mg/g) & 725 \\
\hline
\end{tabular}

\subsection{Adsorption studies}

All experiments were carried out using a known weight of charcoal of potato peel contacted with $200 \mathrm{~mL}$ of $\mathrm{Cr}(\mathrm{VI})$ solution of different concentrations $(2-10 \mathrm{mg} / \mathrm{L})$ using 250 $\mathrm{mL}$ volumetric flasks. The flasks were gently agitated for a specific time at different temperature in an incubator shaker at $150 \mathrm{rpm}$. Samples of solutions were taken out at each time and centrifuged for $10 \mathrm{~min}$ at $2500 \mathrm{rpm}$. The supernatant was separated using a syringe and filter discs $(0.20 \mu \mathrm{m})$ and analyzed colometeriy by adding 1,5- diphenylcarbohydrazide in acidic solution. The product of purple complex of $\mathrm{Cr}(\mathrm{VI})$ was analysed using a Jenway 6700 UV spectrophotometer (Clesceriet al., 1998). The molar absorptivity of this reaction at $540 \mathrm{~nm}$ is approximately $40000 \mathrm{Lg}-1 \mathrm{~cm}-1$. Adsorption of $\mathrm{Cr}$ (VI) ion to the wall of the glassware was examined under operating conditions showing no adsorption.

The percentage removal of $\mathrm{K}_{2} \mathrm{Cr}_{2} \mathrm{O}_{7}$ and equilibrium adsorption capacity (qe) were calculated using the following equations:

$$
\begin{array}{r}
\% \text { Removal }=\frac{C_{o}-C_{t}}{C_{o}} * 100 \% \\
q \mathrm{e}=\left(\mathrm{C}_{0}-\mathrm{C}_{\mathrm{e}}\right) \mathrm{V} / \mathrm{M}(2)
\end{array}
$$

Where $C_{0}$ is the initial concentration $(\mathrm{mg} / \mathrm{L})$ of the $\mathrm{Cr}(\mathrm{VI})$ ions in solution, $C_{\mathrm{t}}$ and $\mathrm{C}_{\mathrm{e}}$ are the concentrations at a specific time and equilibrium respectively, $V$ is the volume of solution by $\mathrm{L}$ and $M$ is the weight of the potato peel by $\mathrm{g}$, the unite of qe is $\mathrm{mg} / \mathrm{g}$.

The effect of several parameters on the adsorption efficiency of chromium (VI) ions onto potato peels was investigated including contact time, adsorption equilibrium, adsorbent dose, $\mathrm{pH}$, temperature and adsorption isotherm and kinetic.

\section{RESULTS AND DISCUSSION}

\subsection{Effect of contact time}

Study the effect of contact time showed increasing in the adsorption percentage of $\mathrm{Cr}(\mathrm{VI})$ on potato peels with increasing the contact time (Fig. 1). The adsorption\% was $94 \%$ after 35 min then it becomes constant attaining equilibrium with increase in contact time. It is clear that, at the beginning a large number of vacant surface sites on potato peel are available for adsorption of $\mathrm{Cr}(\mathrm{VI})$ ions but these surface sites become exhausted with passage of time (Zhan et al., 2000). A $35 \mathrm{~min}$ of contact time was chosen for all further work.

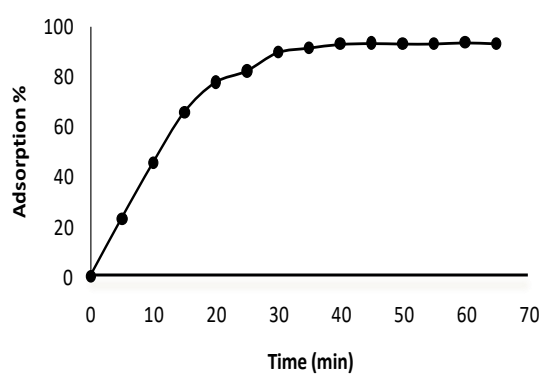

Figure1. Effect of contact time on adsorption of $\mathrm{Cr}(\mathrm{VI})$ ions on $\mathrm{PP}$

\subsection{Effect of initial concentration of $\mathrm{Cr}(\mathrm{VI})$}

Fig. 2 shows the effect of initial concentration of $\mathrm{Cr}(\mathrm{VI})$ (2 to $10 \mathrm{ppm}$ ) on the removal of metal ions by PP. The removal percentage was found to decrease with increase in initial metal concentration. However, the quantity adsorbed per mass unit of PP (Qe) showed increasing with increasing in the concentration of $\mathrm{Cr}(\mathrm{VI})$ (Fig. 3). A possible explanation for this might be attributed that no sufficient surface sites available to adsorb more chromium ions from the solution (Mutongo et al., 2014). The ratio of available active sites to the total $\mathrm{Cr}(\mathrm{VI})$ ions in the solution is high at low concentration, therefore, all ions can interact with PP and are adsorbed rapidly from the solution. However, at high concentration, the quantity adsorbed of $\mathrm{Cr}(\mathrm{VI})$ ions per mass unit of $\mathrm{PP}(\mathrm{Qe})$ is higher (Abdel Wanees et al., 2012). At initial chromium concentration of $10 \mathrm{ppm}$, the adsorption percentage is $87.6 \%$, whilst $2 \mathrm{ppm}$ showed a removal of $98.5 \%$.

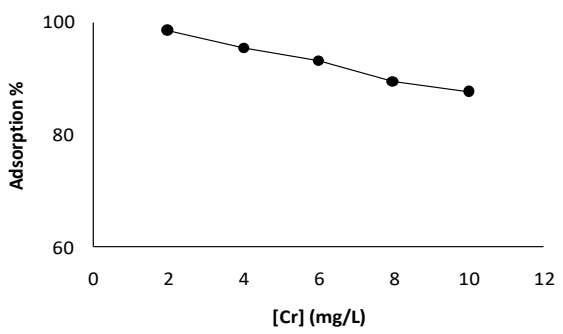

Figure 2. Effect of initial concentration on adsorption of $\mathrm{Cr}(\mathrm{VI})$ ions

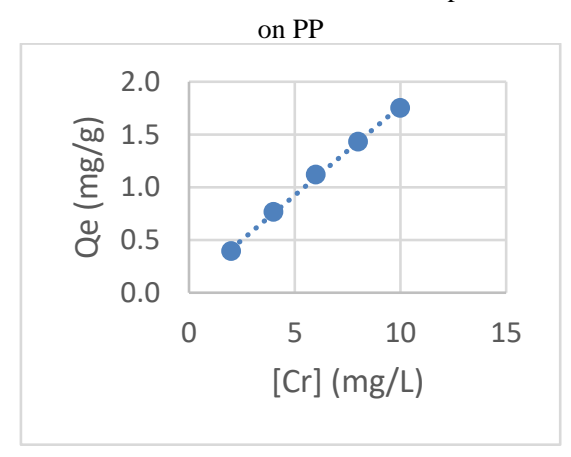

Figure 3. Effect of initial concentration on quantity adsorbed of $\mathrm{Cr}(\mathrm{VI})$ ions on PP

\subsection{Effect of adsorbent dose}

Adsorption experiments were also performed at different weights (namely $0.2,0.4,0.6,0.8,1,2$ and $3 \mathrm{~g}$ ) of potato peels. The adsorption percentage increased with an increasing in PP dosage (Fig. 4). This might be attributed to high surface area of the adsorbent are available for adsorption (Namasivayam et al., 1998; Garg et al., 2007). Maximum removal (97\%) was observed with PP weight of 2 and $3 \mathrm{~g}$. 


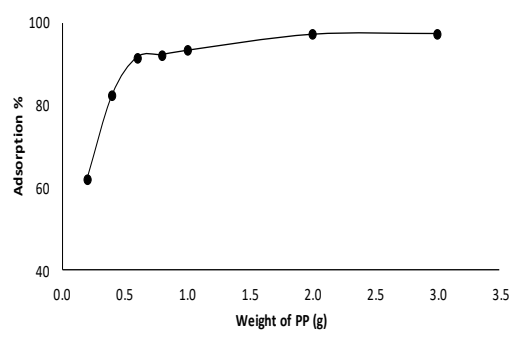

Figure 4. Effect of variant potato peels adsorbent dosage on the adsorption of $\mathrm{Cr}(\mathrm{VI})$ ions

\subsection{Effect of pH}

The effect of $\mathrm{pH}$ on process of adsorption movement on potato peels was investigated at different $\mathrm{pH}$ ranging from 2 to 12 (Fig. 5). No big $\mathrm{pH}$ effect was found, the removal efficiency was close values (approximately $92 \%, \mathrm{RSD} \%=1$ ) at all $\mathrm{pH}$.

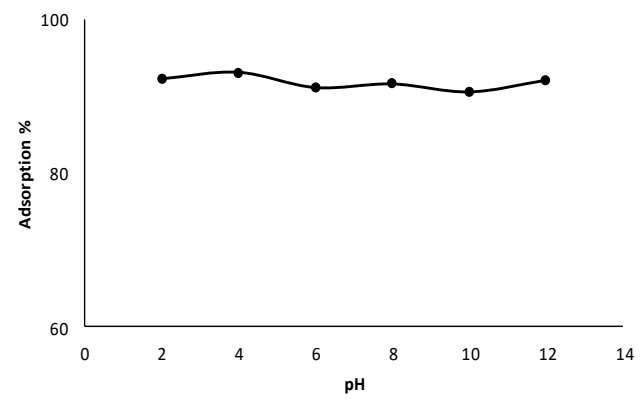

Table 2. The optimum conditions of adsorption $\mathrm{Cr}(\mathrm{VI})$ ions on potato

\begin{tabular}{|c|c|c|c|c|c|}
\hline $\begin{array}{c}\text { Contact } \\
\text { time }\end{array}$ & $\begin{array}{c}\text { Initial } \\
\text { conc. }\end{array}$ & $\begin{array}{c}\text { Adsorbent } \\
\text { dose }\end{array}$ & $\mathrm{pH}$ & Temperature & $\begin{array}{c}\text { Agitation } \\
\text { speed }\end{array}$ \\
\hline $35 \mathrm{~min}$ & $\begin{array}{c}6 \\
\mathrm{mg} / \mathrm{L}\end{array}$ & $1 \mathrm{~g}$ & 6 & $25^{\circ} \mathrm{C}$ & $450 \mathrm{rpm}$ \\
\hline
\end{tabular}

\subsection{Adsorption isotherm}

Adsorption isotherm was investigated selecting fixed PP dosage at $1 \mathrm{~g}$ and various concentrations of $\mathrm{K}_{2} \mathrm{Cr}_{2} \mathrm{O}_{7}(2-10$ $\mathrm{mg} / \mathrm{L}$ ). A number of models are described adsorption isotherms but Langmuir and Freundlich are more familiar models used (Malik, 2004; Gupta andBabu, 2006; Saradhiet al., 2010).

The Langmuir model can be expressed in a nonlinear form as following equation (Langmuir, 1918):

$$
q_{e}=\frac{Q_{m} b C_{e}}{1+b C_{e}}
$$

Where $\mathrm{C}_{\mathrm{e}}$ is the concentration of sorbent $(\mathrm{mg} / \mathrm{L})$ at equilibrium, $\mathrm{Q}_{\mathrm{m}}$ represents to the maximum adsorption capacity $(\mathrm{mg} / \mathrm{g}), \mathrm{q}_{\mathrm{e}}$ is the mass of metal ion adsorbed per unit dose of adsorbent at equilibrium $(\mathrm{mg} / \mathrm{g}), \mathrm{b}$ refers to Langmuir isotherm constant $(\mathrm{L} / \mathrm{mg})$. $\mathrm{Q}_{\mathrm{m}}$ and $\mathrm{b}$ values can be obtained by rearranging the equation 3:

$$
\frac{\mathrm{C}_{\mathrm{e}}}{\mathrm{q}_{\mathrm{e}}}=\frac{1}{\mathrm{bQ}_{\mathrm{m}}}+\frac{\mathrm{C}_{\mathrm{e}}}{\mathrm{Q}_{\mathrm{m}}}
$$

Plotting of $\mathrm{C}_{\mathrm{e}} / \mathrm{q}_{\mathrm{e}}$ versus $\mathrm{C}_{\mathrm{e}}$ suggests the applicability of Langmiur model shown in Fig.7. $\mathrm{Q}_{\mathrm{m}}$ and $\mathrm{b}$ values were determined from the slope and intercept of the liner plot to be 1.97 and 4.2 respectively. The maximum adsorption capacity in present work is lower than that mentioned in previous studies (Abdullah andPrasad 2009; Mutongoet al., 2014).

\section{Figure 5. Effect of $\mathrm{pH}$ on adsorption of $\mathrm{Cr}(\mathrm{VI})$ ions on $\mathrm{PP}$}

\subsection{Effect of temperature}

Temperature is an important parameter that determines the thermodynamic of adsorption process. Six different temperatures were investigated (namely 25, 30, 35, 40, 45 and $50 \mathrm{o}$ C). As presented in Fig. 6, the adsorption percentage was the same $(92 \%$ approximate, $\mathrm{RSD} \%=0.8)$ at all temperatures. This can be explained to saturation of available binding sites on PP hence no more ions can be adsorbed particularly the number of active sites on the adsorbent surface is constant.

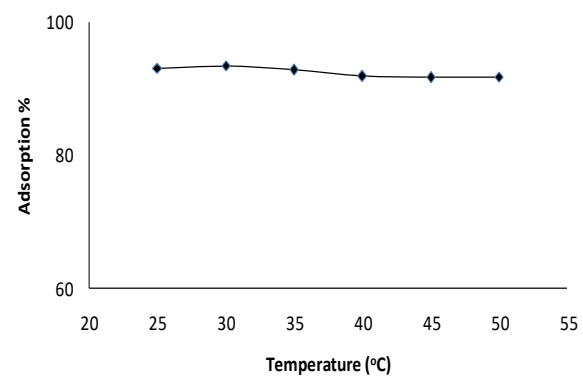

Figure 6. Effect of temperature on adsorption of $\mathrm{Cr}(\mathrm{VI})$ ions on $\mathrm{PP}$

\subsection{Optimum conditions}

The optimum conditions in this study can be summarized as shown in Table 2.

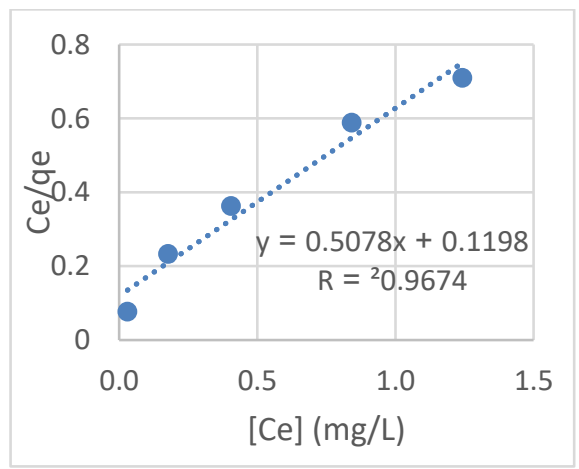

Figure 7. Langmiur isotherm

On the other hand, Freundlich isotherm can be written as equation 5:

$$
q_{e}=K_{f} C_{e}^{1 / n_{f}}
$$

Freunlidh model can be applied for heterogeneous surfaces or non-ideal adsorption (Riveroet al., 2004). Where nf and Kf are Freundlich constants and determined by equation 6 :

$$
\ln \mathrm{q}_{\mathrm{e}}=\ln \mathrm{K}_{\mathrm{f}}+\frac{1}{\mathrm{n}_{\mathrm{f}}} \ln \mathrm{C}_{\mathrm{e}}
$$

Plotting of lnqe versus lnCe obeys the Freundlich isotherm (Fig. 8). kf and nf values were determined from the plot to be 1.57 and 2.5 respectively. 


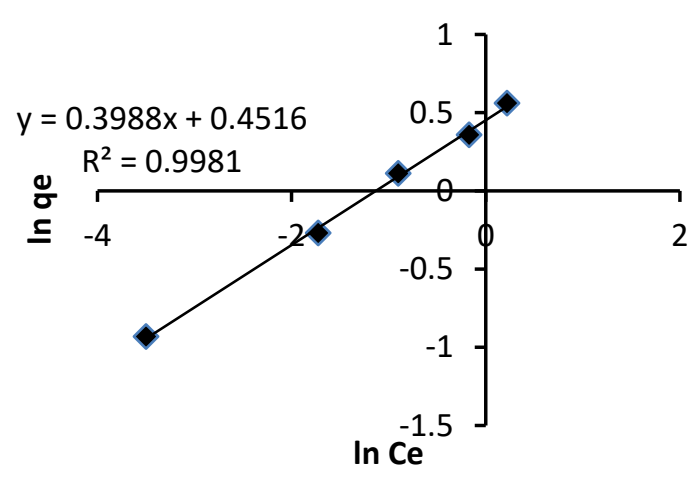

Figure 8. Freundlich isotherm

\subsection{Adsorption Kinetic}

An adsorption kinetic process was investigated applying pseudo first-order and pseudo second-order models. The pseudo first-order model can be described in the following equation (Chiou and Li, 2003):

$$
\ln \left(q_{e}-q_{t}\right)=\ln q_{e}-k_{1} t
$$

Where $\mathrm{q}_{\mathrm{e}}$ is the quantity adsorbed $(\mathrm{mg} / \mathrm{g})$ at equilibrium, $\mathrm{q}_{\mathrm{t}}$ is the quantity adsorbed at specific time $\mathrm{t}, \mathrm{k}_{1}$ is constant $\left(\mathrm{min}^{-1}\right)$ which can be calculated from the linear plot of $\ln \left(\mathrm{q}_{\mathrm{e}}-\mathrm{q}_{\mathrm{t}}\right)$ versus $\mathrm{t}$ (Fig. 9).

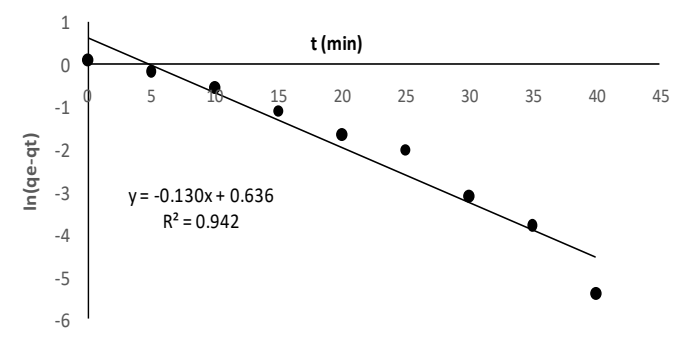

Figure 9. Pseudo first-order kinetic plot

In pseudo-second order model, the adsorption rate depends on the adsorbent capacity and adsorbate concentration (McKay and Ho, 1999). This model is written as:

\section{$t / q t=1 / k_{2} q e^{2}+t / q e(8)$}

Where $\mathrm{k}_{2}$ is constant $\left(\mathrm{g} \mathrm{mg}^{-1} \mathrm{~min}^{-1}\right)$ and determined from the intercept of the plot of $\mathrm{t} / \mathrm{q}_{\mathrm{t}}$ versus $\mathrm{t}$, and $\mathrm{q}_{\mathrm{e}}$ can be calculated from the slope (Fig. 10).

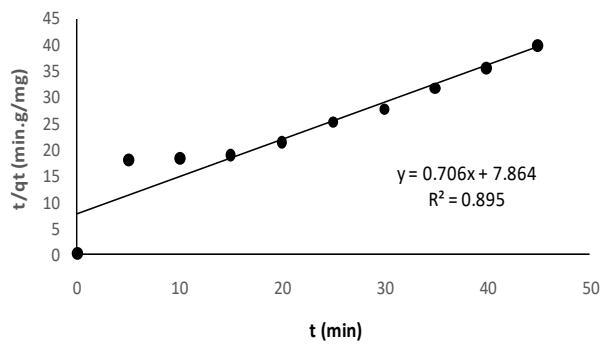

Figure 10. Pseudo second-order kinetic plot
Table 3 shows kinetic parameters of both models. Based on $\mathrm{R}^{2}$ values, the adsorption of $\mathrm{Cr}(\mathrm{VI})$ ions on potato peel was found to be more fit with the pseudo first-order than the pseudo second order model suggesting that the rate limiting step might not be chemisorptions.Table 3. Kinetic parameters

\begin{tabular}{|c|c|c|c|c|c|}
\hline \multicolumn{3}{|c|}{ Pseudo first order } & \multicolumn{3}{|c|}{ Pseudo second order } \\
\hline $\begin{array}{c}\mathbf{k}_{\mathbf{1}} \\
\left(\mathbf{m i n}^{-\mathbf{1}}\right)\end{array}$ & $\mathbf{R}^{\mathbf{2}}$ & $\mathbf{q e}(\mathbf{m g} / \mathbf{g})$ & $\begin{array}{c}\mathbf{k}_{\mathbf{2}}(\mathbf{g} \\
\mathbf{m g}^{-1} \\
\left.\mathbf{m i n}^{-\mathbf{1}}\right)\end{array}$ & $\mathbf{R}^{\mathbf{2}}$ & $\mathbf{q e}(\mathbf{m g} / \mathbf{g})$ \\
\hline 0.130 & 0.942 & 1.730 & 0.063 & 0.895 & 1.410 \\
\hline
\end{tabular}

\section{CONCLUSION}

The potential of using a solid waste of potato peel as a good adsorbent for the removal of $\mathrm{Cr}$ (VI) from aqueous solutions was investigated. The results of batch adsorption experiments elucidate the removal percentage of metal ion from its solution. The adsorption capacity strongly depends on initial concentration of metal ions, contact time with PP, and adsorbent dosage. However, no big $\mathrm{pH}$ and temperature effects were observed giving removal efficiency close to $92 \%$. The chromium adsorption follows the Langmuir and Freundlich isotherm models suggesting that both monolayer and heterogeneous surface adsorption affect the biosorption. The adsorption kinetic was found to be more fit with the pseudo firstorder than the pseudo second order model.

\section{REFERENCES}

Abdel Wanees, S., Ahmed, A. M. M., Adam, M. S.,and Mohamed, M. A. (2012). Adsorption Studies on the Removal of Hexavalent Chromium-Contaminated Wastewater using Activated Carbon and Bentonite. Chemistry Journal, 2 (3): 95-105.

Abdullah, M. A.,and Prasad, A. G. D. (2009). Kinetics and equilibrium studies for the biosorption of $\mathrm{Cr}$ (VI) from aqueous solutions by potato peel waste. International Journal of Chemical Engineering Research, 1(2): 51-62.

Aman, T., Kazi, A. A., Sabri, M. U., andBano, Q. (2008). Potato Peels as solid waste for the removal of heavy metal copper (II) from waste water/industrial effluent. Colloids and Surfaces B, Biointerfaces, 63 (1): 116-121.

Anirudhan,T. S.,andRadhakrishnan, P. G. (2008). Thermodynamics and kinetics of adsorption of $\mathrm{Cu}$ (II) from aqueous solutions onto a new cation exchanger derived from tamarind fruit shell. Journal of Chemical Thermal, 40(4): 702-709.

Bailey, E. S., Trudy, O. J., Mark, B. R., and Dean, A. D. (1998).A review of potentially low cost sorbents for heavy metals. Water Research, 33 (11): 2469-2479.

Chiou, M.S., and Li, H.Y. (2003).Adsorption behaviour of reactive dye in aqueous solution on chemicalcross-linked chitosan beads.Chemosphere, 50 (8): 1095-1105.

Clesceri, L. S., Greenberg, A. E.,and Eaton, A. D. (1998).Standard Methods for the Examination of Water and Wastewater, APHA, WEF, AWWA.American Public Health Association, Washington, DC, USA, 20th edition.

Deng, L., Su, Y., Su, H., Wang, X., and Zhu, X. (2006).Biosorption of copper (II) and lead (II) from aqueous solutions by nonliving green algae Cladophorafascicularis: Equilibrium, kinetics and environmental effects. Adsorption, 12, (4): 267-277.

Durga, C., Prasad, P. S., Krishna, P.,andSrinivas, C. (2012). Equilibrium studies on biosorption of chromium on Psidiumguajavaleavespowder. Journal of Chemical and Pharmaceutical Research, 4 (4):1868-1879.

EPA (1990).Environmental Pollution Control Alternatives.E.P. Agency, Cincinnati, US.

Garg, U. K., Kaur, M. P., Garg, V. K., andSud, D. (2007).Removal of hexavalent chromium from aqueous solution by agricultural waste biomass.Journal of Hazardous Materials, 140 (1-2): 60-68.

Guechi, E. K., andHamdaoui, O. (2011). Sorption of malachite green from aqueous solution by potato peel: Kineticsand equilibrium modeling using non-linear analysis method. Arabian Journal of Chemistry, 4 (3): 243-260. 
Gupta, S., andBabu, B. V. (2006). Adsorption of Cr(VI) by a low-cost adsorbent prepared from neem leaves. Proceeding of National Conference on Environmental Conservation, 1-3 Sep: $175-180$

Hasan, S. H., Singh, K. K., Prakash, O., Talat, M., and Ho, Y. S. (2008). Removal of $\mathrm{Cr}(\mathrm{VI})$ from aqueous solutions using agriculturalwaste 'maize bran'. Journal of Hazardous Materials, 152 (1): 356-365.

Krishna, R. H.,andSwamy, A. V. S.(2012). Studies on removal of $\mathrm{Cr}$ (VI) from aqueous solutions using powder of mosambi fruit peelings (PMFP) as a low cost sorbent.E-Journal of Chemistry, 9, (3): 1389-1399.

Langmuir, I. (1918).The adsorption of gases on plane surfaces of glass, mica and platinum.Journal of theAmerican Chemical Society, 40(9): 1361-1403.

Li, H., Li, Z., Liu, T., Xiao, X., Peng, Z., and Deng, L. (2008).A novel technology for biosorption and recovery of hexavalent chromium in wastewater by bio-functional magnetic beads.Bioresource Technology, $99 \quad$ (14): 62716279 .

Li, X., Tang, Y., Cao, X., Lu, D., Luo, F., and Shao, W (2008).Preparation and Evaluation of Orange Peel Cellulose Adsorbents for Effective Removal of Cadmium, Zinc, Cobalt and Nickel.Colloids and Surfaces, 317 (1-3): 512-521.

Malik, P. K. (2004). Dye removal from wastewater using activated carbon developed from sawdust: adsorption equilibrium and kinetics. Journal of Hazardous Materials, 113 (1-3): 81-88.

McKay, G., and Ho, Y.S. (1999).Pseudo-second order model for sorption process.Process Biochem, 34 (5): 451-465.

Mohan, D., and Pittman, C. J.(2006). Activated carbons and low cost adsorbents for remediation of tri and hexavalent chromium for water.Journal of hazardous materials, 137 (2): 762-811.
Monser, L., andAdhoum, N. (2002).Modified activated carbon for the removal of copper, zinc, chromium and cyanide from wastewater.Separation and Purification Technology, 26 (2): 137-146.

Mutongo, F., Kuipa, O.,andKuipa, P. K. (2014). Removal of Cr(VI) from Aqueous Solutions Using Powder of Potato Peelings as a Low Cost Sorbent. Bioinorganic Chemistry and Applications, Article ID 973153, 7 pages, doi: 10.1155/2014/973153.

Namasivayam, C., Kadirvelu, K.,andKumuthu, M. (1998).Removal of direct red and acid brilliant blue by adsorption onto banana pith.Bioresource Technology, 64 (1): 77-79.

Rivero, M. J., Primo, O., and Ortiz, M. I. (2004).Modelling of Cr(VI) removal from polluted ground waters by ion exchange. Journal of Chemical Technology and Biotechnology, 79 (8): 822-829.

Sallau, A. B., Aliyu, S.,andUkuwa, S. (2012). Biosorption of chromium(VI) from aqueous solution by corn cob powder. International Journal of Environment and Bioenergy, 4 (3): 131-140.

Saradhi, B. V., Rao, S. R. K., Kumar, Y. P., Vijetha, P., Venkata R. K., andKalyani, G. (2010).Applicability of Freundlich and Langmuir theory for biosorption of chromium from aqueous solution using test of sea urchin.International Journal of Chemical Engineering Research,2 (2):139-148.

Sikaily, A. E., Nemr, A. E., Khaled, A., andAbdelwehab, O. (2007). Removal of toxic chromium from waste water using green alga Ulvalactuca and its activated carbon.Journal of Hazardous Materials, 148, (1- 2): 216-228.

Zhan, Y. B., Shukla, A., Shukla, S., andDorris, K.L. (2000).The removal of heavy metal from aqueous solutions by sawdust adsorption-removal of Copper.Journal of Hazardous Materials, 80(1-3): 33-42. 